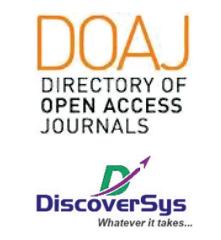

Published by DiscoverSys

\section{Efek pemberian ekstrak etanol bawang putih (Allium sativum) sebagai hepatoprotektor pada tikus putih jantan galur wistar (Rattus norvegicus) yang diinduksi parasetamol dosis hepatotoksik}

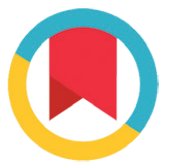

CrossMark

\author{
I Made Subhawa Harsa*
}

\title{
ABSTRACT
}

Garlic (Allium sativum) is a plant that known to have various properties that can be used in treatment as a hepatoprotective agent. This study aim was to determine the effect of garlic ethanol extract (Allium sativum) in Wistar strain white male rats (Rattus norvegicus) which was induced by paracetamol in hepatotoxic dose. This research is an experimental study with randomized the post-test only control group design with sample consisted of twenty-four Wistar strain white male rats (Rattus norvegicus). The sample were divided into four groups: control groups, group P1 (given garlic ethanol extract $10 \mathrm{mg} / \mathrm{kg}$ ), group P2 (ethanol extract of garlic was given $20 \mathrm{mg} /$ $\mathrm{kg}$ ) and group P3 (given the ethanol extract garlic $30 \mathrm{mg} / \mathrm{kg}$ ). This study for seventeen days. The entire samples were terminated in order to draw blood to examine SGPT and SGOT. The data of SGPT and SGOT examined by One Way ANOVA. Result showed that there was significant difference in SGPT and SGOT values between groups after given ethanol extract of garlic (Allium sativum) $(a<0.05)$. From the analysis we can concluded that garlic ethanol extract (Allium sativum) can be used as a hepatoprotective agent in Wistar strain white male rats (Rattus norvegicus) induced by paracetamol in hepatotoxic dose.
Staff, Bagian IImu Faal Fakultas Kedokteran Universitas Wijaya Kusuma, Surabaya, Indonesia.
*Korespodensi:

I Made Subhawa Harsa, Staff, Bagian IImu Faal Fakultas Kedokteran Universitas Wijaya Kusuma, Surabaya, Indonesia. madesubhawah@gmail.com

Diterima: 25-11-2019 Disetujui: 04-01-2020 Diterbitkan: 04-04-2020
Keywords: Ethanol extract of garlic, Hepatoprotective, Paracetamol

Cite This Article: Harsa, I.M.S. 2020. Efek pemberian ekstrak etanol bawang putih (Allium sativum) sebagai hepatoprotektor pada tikus putih jantan galur wistar (Rattus norvegicus) yang diinduksi parasetamol dosis hepatotoksik. Intisari Sains Medis 11(1): 118-121. D0l: 10.15562/ism. v11i1.666

\section{PENDAHULUAN}

Perkembangan teknologi yang semakin pesat menyebabkan perubahan pola hidup masyarakat. Salah satunya dalam hal konsumsi obat-obatan. Pemakaian obat tanpa indikasi jelas dan tidak sesuai dengan dosis terapeutik yang seharusnya digunakan dapat menyebabkan berbagai kerugian, diantaranya kerusakan pada berbagai organ tubuh penggunanya. ${ }^{1}$ Asetaminofen merupakan salah satu obat yang penggunaannya sering di salah gunakan. Di Indonesia, asetaminofen lebih dikenal dengan nama parasetamol, dan tersedia sebagai obat bebas. ${ }^{2}$ Parasetamol merupakan sebuah analgesik sintetik non-opiat yang berasal dari metabolit fenasetin yang juga mempunyai daya kerja antipiretik, namun tidak mempunyai daya kerja antiradang. ${ }^{3}$

Pemakaian dalam jumlah berlebihan dan jangka waktu yang lama menimbulkan efek toksik. Efek toksik terjadi akibat terbentuknya metabolit yang merupakan hasil metabolisme parasetamol yang mengalami proses oksidasi $\mathrm{N}$-hidroksilasi dengan bantuan sitokrom P-450 pada hepar. ${ }^{4} \mathrm{Hal}$ itu dikarenakan pembentukan metabolit reaktif toksik (N-asetil-p-benzoquinon) dan radikal bebas dapat mengganggu integritas membran sel dan berlanjut menjadi kerusakan hepatosit. ${ }^{5}$ Kelainan atau kerusakan hati ditandai dengan meningkatnya beberapa parameter biokimia hepar yang dapat dilihat di darah seperti serum glutamat piruvat transaminase (SGPT) dan serum glutamat oksaloasetat transminase (SGOT). ${ }^{6}$

Sejak ribuan tahun yang lalu, penggunaan obat tradisional telah digunakan dengan memanfaatkan tumbuhan berkhasiat obat sebagai pengobatan untuk mencapai kesehatan yang optimal secara alami. Salah satunya adalah bawang putih (Allium sativum) yang dipercaya memiliki berbagai khasiat yang dapat digunakan dalam pengobatan, diantaranya sebagai antimikroba, antitrombosis, antitumor, antihiperlipidemia, antioksidan dan kemampuannya sebagai hepatoprotektor. ${ }^{7}$ Beberapa komponen aktif dalam bawang putih yang memiliki fungsi fungsional yaitu senyawa yang mengandung sulfur, termasuk allicin, diallyl disulfide dan diallyl trisulfide, semua merupakan minyak yang mudah menguap (volatil), serta S-allyl cysteine (SAC) dan S-allyl-mercaptocystein (SAMC), asam amino yang larut dalam air.8 


\section{METODE PENELITIAN}

Penelitian ini merupakan penelitian analitik eksperimental murni dengan metode randomized post-test only control group design. ${ }^{9}$ Variabel dalam penelitian ini meliputi variabel terikat kadar SGPT dan SGOT pada darah tikus putih jantan galur Wistar (Rattus norvegicus) yang sebelumnya telah diinduksi parasetamol dengan dosis hepatotoksik dan yang sebelumnya telah diberikan ekstrak etanol bawang putih (Allium sativum), sedangkan variabel bebas yaitu dosis ekstrak etanol bawang putih (Allium sativum). Dalam penelitian ini menggunakan tikus jantan galur Wistar (Rattus norvegicus) yang berumur 3-4 bulan dengan berat kurang lebih 140-200 gram dengan jumlah sampel 24 ekor tikus dibagi menjadi empat kelompok secara random yaitu kelompok kontrol yang hanya diinduksi parasetamol dosis $500 \mathrm{mg} / \mathrm{kgBB}$ selama 10 hari, kelompok perlakuan 1 (P1) yang diberikan ekstrak etanol bawang putih $10 \mathrm{mg} / \mathrm{kgBB}$, kelompok perlakuan 2 (P2) yang diberikan ekstrak etanol bawang putih $20 \mathrm{mg} / \mathrm{kgBB}$ dan kelompok perlakuan
3 (P3) yang diberikan ekstrak etanol bawang putih $30 \mathrm{mg} / \mathrm{kgBB}$. Seluruh ekstrak etanol bawang putih diberikan secara oral sebagai preventif selama 7 hari, satu kali sehari lalu diinduksi parasetamol dosis $500 \mathrm{mg} / \mathrm{kgBB}$ selama10 hari. Seluruh hewan coba diterminasi untuk diambil darahnya guna pemeriksaan SGPT dan SGOT. Data yang telah dikumpul kemudian diproses dengan uji One Way ANOVA

\section{HASIL PENELITIAN}

Setelah dilakukan penelitian mengenai efek hepatoprotektor ekstrak etanol bawang putih (Allium sativum) pada tikus yang diinduksi parasetamol dosis hepatotoksik didapatkan hasil sebagai berikut;

\section{Kadar SGPT Sesudah Perlakuan}

Uji kemaknaan dengan One Way ANOVA, pada data kadar SGPT nilai $f$ didapatkan 10,426 dengan $\mathrm{p}=0,000$. Hal ini menunjukkan adanya perbedaan bermakna sesudah diberikan perlakuan pada keempat kelompok coba $(\alpha<0,05)$.

Tabel 1 Rerata SGPT antar kelompok sesudah diberikan perlakuan

\begin{tabular}{|c|c|c|c|c|c|c|}
\hline \multirow[b]{2}{*}{ Kelompok } & \multicolumn{6}{|c|}{ ALT (SGPT) } \\
\hline & $\mathbf{n}$ & Mean & + & SD & $\mathbf{f}$ & Nilai p \\
\hline $\begin{array}{l}\text { Kontrol } \\
\text { Induksi parasetamol } 500 \mathrm{mg} / \mathrm{kgBB}\end{array}$ & 6 & 91,17 & + & 10,08 & & \\
\hline $\begin{array}{l}\text { Perlakuan } 1 \\
\text { Bawang putih } 0,25 \mathrm{ml}+\text { parasetamol } \\
500 \mathrm{mg} / \mathrm{kgBB}\end{array}$ & 6 & 78,83 & + & 6,01 & & \\
\hline $\begin{array}{l}\text { Perlakuan } 2 \\
\text { Bawang putih } 0,5 \mathrm{ml}+\text { parasetamol } 500 \\
\mathrm{mg} / \mathrm{kgBB}\end{array}$ & 6 & 65,5 & + & 6,38 & 10,426 & 0,000 \\
\hline $\begin{array}{l}\text { Perlakuan } 3 \\
\text { Bawang putih } 1 \mathrm{ml}+\text { parasetamol } 500 \\
\mathrm{mg} / \mathrm{kgBB}\end{array}$ & 6 & 45,6 & + & 7,23 & & \\
\hline
\end{tabular}

Tabel 2 Rerata SGOT antar kelompok sesudah diberikan perlakuan

\begin{tabular}{|c|c|c|c|c|c|c|}
\hline \multirow[b]{2}{*}{ Kelompok } & \multicolumn{6}{|c|}{ AST (SGOT) } \\
\hline & $\mathbf{n}$ & Mean & + & SD & $f$ & Nilai p \\
\hline $\begin{array}{l}\text { Kontrol } \\
\text { Induksi parasetamol } 500 \mathrm{mg} / \mathrm{kgBB}\end{array}$ & 6 & 134,5 & + & 14,83 & & \\
\hline $\begin{array}{l}\text { Perlakuan } 1 \\
\text { Bawang putih } 0,25 \mathrm{ml}+\text { parasetamol } \\
500 \mathrm{mg} / \mathrm{kgBB}\end{array}$ & 6 & 122 & + & 5,09 & & \\
\hline $\begin{array}{l}\text { Perlakuan } 2 \\
\text { Bawang putih } 0,5 \mathrm{ml}+\text { parasetamol } 500 \\
\mathrm{mg} / \mathrm{kgBB}\end{array}$ & 6 & 109,66 & + & 7,76 & 39,431 & 0,000 \\
\hline $\begin{array}{l}\text { Perlakuan } 3 \\
\text { Bawang putih } 1 \mathrm{ml}+\text { parasetamol } 500 \\
\mathrm{mg} / \mathrm{kgBB}\end{array}$ & 6 & 102,33 & + & 12,42 & & \\
\hline
\end{tabular}




\section{Kadar SGOT Sesudah Perlakuan}

Uji kemaknaan dengan One Way ANOVA pada data kadar SGOT nilai f didapatkan 39,431 dengan $\mathrm{p}=0,000$. Hal ini menunjukkan adanya perbedaan bermakna sesudah diberikan perlakuan pada keempat kelompok coba $(\alpha<0,05)$.

\section{DISKUSI}

Pada kelompok perlakuan yang diberikan ekstrak etanol bawang putih (Allium sativum) sebagai prevensi didapatkan aktivitas SGPT dan SGOT yang lebih rendah dibandingkan dengan aktivitas SGPT dan SGOT kelompok kontrol yang tidak diberikan ekstrak etanol bawang putih (Allium sativum) sebagai prevensi. Hal ini disebabkan karena dalam ekstrak etanol bawang putih (Allium sativum) terdapat kandungan senyawa aktif yang bersifat hepatoprotektor melalui berbagai mekanisme, diantaranya salah satu kandungan aktif yang terkandung dalam bawang putih yaitu allyl-propyl-disulfide berfungsi dalam meningkatkan produksi gluthatione dimana gluthatione merupakan suatu reduktor intraseluler yang tersebar dalam sel dan berfungsi dalam katalisis, metabolisme dan transportasi. Gluthatione melindungi sel dari radikal bebas, peroksida dan bahan toksik lainya, yang dalam hal ini gluthatione kemudian berikatan dengan metabolit reaktif dari parasetamol yaitu $\mathrm{N}$-asetilp-benzokuinonimin (NAPQI) dan meningkatkan ekskresinya dari tubuh. ${ }^{10}$ Selain itu penelitian yang telah dilakukan oleh Kumar et. al. pada tahun 2013 juga membuktikan bahwa bawang putih dapat memperbaiki kestabilan membran sel hepatosit dan melindungi hepar terhadap agen hepatotoksik dan kerusakan yang dimediasi oleh radikal bebas pada sel-sel hepatosit. ${ }^{11} \mathrm{Hal}$ ini tercermin dalam pengurangan enzim hepar. Selain itu zat-zat yang terkandung dalam bawang putih (Allium sativum) berfungsi dalam menjaga fungsi normal hepar dengan mempercepat kapasitas regenerasi sel-selnya. ${ }^{12,13}$

Suatu derivat organosulfur larut air dalam bawang putih yaitu S-allylmercapto-L-cysteine (SAMC) bersama-sama dengan S-allyl-L-cysteines (SAC) berfungsi sebagai antioksidan yang berperan dalam mekanisme inhibisi peningkatan enzim sitokrom P-450 yang berperan dalam pembentukan NAPQI saat terjadi metabolism parasetamol dan mencegah akumulasi asam lemak bebas dan peningkatan peroksidasi lipid yang terjadi pada sel-sel hepatosit. ${ }^{14}$ sehingga dapat melindungi sel-sel hepatosit dan memperbaiki jejas-jejas yang terjadi pada hepar akibat metabolisme parasetamol dan metabolitnya yang bersifat hepatotoksik. ${ }^{15}$ Selain itu, bawang putih (Allium sativum) juga berperan dalam mempercepat kapasitas regenerasi sel-sel hepatosit untuk mencegah terjadinya kerusakan hepar yang lebih lanjut. ${ }^{16,17}$

\section{SIMPULAN}

Berdasarkan hasil penelitian yang telah dilakukan, dapat disimpulkan bahwa ekstrak etanol bawang putih (Allium sativum) berfungsi sebagai hepatoprotektor pada tikus jantan putih galur Wistar (Rattus norvegicus) yang diinduksi parasetamol dosis hepatotoksik.

\section{KONFLIK KEPENTINGAN}

Tidak terdapat konflik kepentingan dalam penelitian ini.

\section{PENDANAAN}

Penelitian ini tidak mendapatkan pendanaan dari pihak manapun.

\section{DAFTAR PUSTAKA}

1. Riyono A. Paracetamol Dalam Obat Anak-Anak. Poltekes Kementerian Kesehatan Surabaya. 2011.

2. Wilmana PF, Sulistia G. Analgesik-Antipireutik, AnalgesiAnti Inflamasi Non Steroid, Dan Obat Gangguan Sendi Lainnya dalam Farmakologi dan Terapi edisi 5. Jakarta : FK UI. 2009: 237-239.

3. Darsono L. Diagnosis dan Terapi Intoksikasi Salisilat dan Parasetamol. Bandung : Universitas Kristes Maranatha. 2002.

4. Murray MT, Pizzorno JE. Allium sativum (garlic). In: Textbook of natural and medicine. 2 Edition. (eds. J.E. Pizzorno Jr. and M.T. Murray). Edinburgh: Churchill Livingstone. 2009: pp. 571-577.

5. Sagita A. Pengaruh Ekstrak Andrographis paniculata (Sambiloto) Terhadap Kadar Serum Glutamat Oksaloasetat Transaminase Pada Tikus Wistar Yang Diberi Parasetamol. Fakultas Kedokteran Universitas Diponegoro Semarang. 2006.

6. Chopra S. Patterns of Plasma Aspartate and Alanine Aminotransferase Levels with and Without Liver Disease. In: Kaplan MM, Bonis P, editors. Waltham, MA: UpToDate. 2008.

7. Hernawan UE, Setyawan AD. Senyawa Organosulfur Bawang Putih Allium sativum L.) dan Aktivitas Biologisnya. Biofarmasi. 2003: 1 (1): 65-76.

8. Chiang YH et. al. Effects Of Garlic Oil And Two Of Its Major Organosulfur Compounds, Diallyl Disulfide And Diallyl Trisulfide, on Intestinal Damage in Rats Injected with Endotoxin. Toxicology and applied pharmacology. 2006: 213 (1): 46-54.

9. Pocock SJ. Clinical Trials A Practical Approach. England: John Miley \& Son. 2008.

10. Guyonnet D et. al. Mechanisms of Protection Against Aflatoxin B1 Genotoxicity in Rats Treated By Organosulfur Compounds from Garlic. Carcinogenesis 2002; 23:1335-1341.

11. Kumar S, Kumar A, Chandra A. Alteration in Serum Biochemical Parameters due to Garlic (Allium sativum) Supplementation in Broiler's Diets. Afr. J. Biotechnology. 2013 . 
12. Ryu KN, Matsura HI, Itakura Y. Na-(1-deoxy-D-fructose1-yl)-L- arginine, An Anti-Oxidant Compound Identified In Aged Garlic Extract. Journal of Nutrition 2001: 131: 972S-976S.

13. Song K, Milner JA. The Influence Of Heating On The Anticancer Properties Of Garlic. Journal of Nutrition. 2001: 131: 1054S- 1057S.

14. Sumioka I, Matsura T. Mechanisms of Protection by S-Allylmercaptocysteine Against Acetaminophen-Induced Liver Injury in Mice. Jpn J Pharmacol. 1998: 78(2):199-207.

15. Tanaka S et. al. Effects Of Aged Garlic Extract (AGE) on Colorectal Adenomas: A Double - Blinded Study. Hiroshima J Med Sci. 2004; 53: 39-45.
16. Banerjee SK. Maulik SK. Effect Of Garlic on Cardiovasculer Disorders: a review. Nutrition Journal. 2002: 1(4): 1-14.

17. Amagase $\mathrm{H}$ et. al. Intake Of Garlic And Bioactive Components. Journal of Nutrition. 2001: 131 (3): 955S- 962 S.

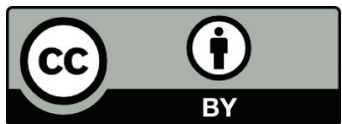

This work is licensed under a Creative Commons Attribution 